\title{
NG2 targets tumorigenic Rb inactivation in Pit1-lineage pituitary cells
}

\author{
Toru Tateno1,*, Tae Nakano-Tateno,,*, Shereen Ezzat1 and Sylvia L Asa² \\ 'Department of Medicine, The Endocrine Oncology Site Group, Princess Margaret Cancer Centre, \\ University Health Network, Toronto, Ontario, Canada \\ 2Department of Pathology, The Endocrine Oncology Site Group, Princess Margaret Cancer Centre, \\ University Health Network, Toronto, Ontario, Canada \\ *(T Tateno and T Nakano-Tateno contributed equally to this work)
}

Correspondence
should be addressed
to S L Asa
Email
sylvia.asa@uhn.ca

\begin{abstract}
The proteoglycan neuron-glial antigen 2 (NG2) is expressed by oligodendrocyte progenitors, pericytes, and some cancerous cells where it is implicated in tumor development. We examined mice with NG2-driven pRb inactivation. Unexpectedly, NG2-Cre:pRb floxfflox mice developed pituitary tumors with high penetrance. Adenohypophysial neoplasms developed initially as multifocal lesions; by 1 year, large tumors showed brain invasion. Immunohistochemistry identified these as Pit1-lineage neoplasms, with variable immunoreactivity for growth hormone, prolactin, thyrotropin, and $\alpha$-subunit of glycoprotein hormones. Other than modest hyperprolactinemia, circulating hormone levels were not elevated. To determine the role of NG2 in the pituitary, we investigated NG2 expression. Immunoreactivity was identified in anterior and posterior lobes but not in the intermediate lobe of the mouse pituitary; in the adenohypophysis, folliculostellate cells had the strongest NG2 immunoreactivity but showed no proliferation in response to $\mathrm{Rb}$ inactivation. Pit1-positive adenohypophysial cells were positive for NG2, but corticotroph and gonadotroph cells were negative. RT-PCR revealed NG2 expression in normal human pituitary and human pituitary tumors; immunohistochemistry localized NG2 in nontumorous human adenohypophysis with strongest positivity in folliculostellate cells, and in tumors of all types except corticotrophs. Functional studies in $\mathrm{GH} 4$ mammosomatotrophs showed that NG2 increases prolactin (PRL), reduces growth hormone (GH) expression, and enhances cell adhesion without influencing proliferation. In conclusion, NG2-driven pRb inactivation results in pituitary tumors that mimic endocrinologically inactive Pit1-lineage human pituitary tumors. This model identifies a role for NG2 in pituitary cell-type-specific functions and unmasks a protective role from $\mathrm{Rb}$ inactivation in folliculostellate cells; it can be used

for further research, including preclinical testing of novel therapies.
\end{abstract}

\section{Introduction}

Pituitary tumors are common, with increasing prevalences being reported (Ezzat et al. 2004, Daly et al. 2006, Fernandez et al. 2009, Fontana \& Gaillard 2009,

\author{
Key Words \\ - NG2 \\ - $\mathrm{pRb}$ \\ - pituitary \\ - tumors
}

Tjornstrand et al. 2014, Agustsson et al. 2015). Although pituitary tumors are usually classified as benign, they can cause significant morbidity due to abnormal hormone

Published by Bioscientifica Ltd. 
production and secretion, and due to symptoms of mass effects, including visual disturbances and invasion into surrounding brain structures (Asa \& Ezzat 2016). Although a minority of these tumors is attributable to familial genetic predisposition, the mechanisms underlying the more common sporadic pituitary tumors rarely involve mutations of classical oncogenes or tumor suppressor genes and have yet to be elucidated (Asa \& Ezzat 2009, 2014, 2016, Asa 2011). In fact, the only consistent genetic alteration reported thus far is activating the mutation of GNAS that occurs in a subset of somatotroph tumors (Asa \& Ezzat 2009, 2014, 2016, Asa 2011).

Neuron-glial antigen 2 (NG2) is a proteoglycan expressed on the surface of a variety of cell types (Levine \& Nishiyama 1996), including oligodendrocyte progenitor cells (Sakry et al. 2014), chondroblasts (Fukushi et al. 2003), myoblasts (Petrini et al. 2003), and pericytes (You et al. 2014). In addition, it is expressed in several cancers such as glioblastoma and melanoma where it is implicated in angiogenesis and proliferation (Wang et al. 2011). In addition, NG2 signaling cross talks with FGF signaling (Wang et al. 2011), which is required for pituitary development and tumor development (Asa \& Ezzat 2009, 2016).

Genetically modified mice, particularly those deficient in cell cycle regulators, frequently develop pituitary tumors; however, these mice are not good models of human pituitary tumors (Asa 2001), because they usually develop undifferentiated tumors that do not phenocopy the human situation. In particular, mice lacking $p R b$ develop undifferentiated tumors of the intermediate lobe, which is only vestigial in the human pituitary gland (Jacks et al. 1992).

In this report, we identify pituitary tumors of Pit1lineage cells in mice with conditional $p R b$ ablation under the control of the NG2 promoter. This new mouse model of anterior pituitary tumor more closely mimics the human situation and also brings to light an important role for NG2 in the pituitary gland. Curiously, NG2 expression is highest in folliculostellate cells, the sustentacular cells of the adenohypophysis, yet our data unmask a novel dispensable role for $\mathrm{Rb}$ in those cells.

\section{Materials and methods}

\section{Generation of constitutive NG2 cell-specific pRb conditional knockout mice}

For constitutive deletion of pRb in NG2 cells, NG2creBAC (Cspg4-cre, Jackson Laboratory strain \#008533) and $p R b$ conditional knockout mice ( $p R b^{f l o x}$ fllox or $p R b^{f l o x /+}$, Jackson Laboratory strain \#008186) were bred to create homozygous NG2creBAC:pRbfloxfllox and heterozygous NG2creBAC:pRfflox/+ transgenic mice; these mice were kindly provided by Dr B Alman (Hospital for Sick Children, Toronto, Ontario, Canada). Only female NG2cre mice were used for breeding, as the NG2cre transgene is spuriously activated by an unknown mechanism in male germ cells in NG2creBAC mice. Offspring mice were genotyped by PCR of the tail DNA samples using the following primers. pRb: Fwd: 5'-GGC GTG TGC CAT CAA TG-3'; Rev: 5'-CTC AAG AGC TCA GAC TCA TGG-3'; Cre: Fwd: 5'-GCG GTC TGG CAG TAA AAA CTA TC-3'; Rev: 5'-GTG AAA CAG CAT TGC TGT CAC TT-3'.

The care of animals was approved by the Institutional Animal Care facilities. The animals were maintained at the Toronto Centre for Phenogenomics, Toronto, Ontario, Canada, and were maintained according to the institutional standards. Mice were killed within $24 \mathrm{~h}$ when they showed any of the following: symptoms of 'head tilt', hunched or abnormal posture, lethargy or reluctance to move, weight loss exceeding $20 \%$ of normal body weight, persistent anorexia and dehydration that could not be alleviated, sunken eyes and pinched face indicative of advanced dehydration, compromised normal behavior, and ambulation or food and water intake.

At the time of killing, blood was collected and tissues were prepared for three types of analysis: frozen in liquid nitrogen and stored at $-70^{\circ} \mathrm{C}$, fixed in formalin and embedded in paraffin for histologic and immunohistochemical analyses, or fixed in glutaraldehyde and embedded in epoxy resin for analyses using transmission electron microscopy.

\section{Histology and immunocytochemistry}

Mouse tissues were collected at autopsy, fixed in formalin, and embedded in paraffin for morphologic examination. All tissues were examined on sections stained with hematoxylin and eosin. Sections of pituitary were stained with the Gordon-Sweet silver method to demonstrate the reticulin fiber network. Immunocytochemical stains to localize adenohypophysial hormones were performed as previously reported (Tateno et al. 2011). Primary antibodies or antisera directed against mouse pituitary hormones and transcription factors were used at the specific dilutions: Pit1 (Santa Cruz) 1:400 after TE9 pretreatment; steroidogenic factor-1 (SF1; Cedarlane, Burlington, Ontario, Cananda) 1:75; estrogen receptor $\alpha$ (ER $\alpha$; Abcam citrate 1/200 after citrate

Published by Bioscientifica Ltd 
pretreatment; GH (National Hormone and Pituitary Program (NHPP), Rockville, MD, USA) 1:2500; PRL (NHPP) 1:2500; thyroid-stimulating hormone (TSH; NHPP) 1:3000; follicle-stimulating hormone (FSH; NHPP) 1:600; luteinizing hormone (LH; NHPP) 1:2500; adrenocorticotropin (ACTH; Dako) prediluted preparation, further diluted 1:20; and $\alpha$-subunit of glycoprotein hormones ( $\alpha \mathrm{SU}$; NHPP) 1:150. Immunostaining was also performed to localize $\mathrm{Rb}$ (Cell Signaling) 1:500 after TE9 pretreatment and CD31 (Santa Cruz) 1:2000 after Tris-EDTA pretreatment. The NG2 antibody RaNG2/EC, an affinity-purified rabbit antirecombinant rat NG2 ectodomain, was kindly provided by Dr W Stallcup (Sanford Burnham Prebys Medical Discovery Institute, La Jolla, CA, USA) and incubated at 1:500 dilution overnight after TE9 pretreatment.

A tissue microarray (TMA) of human pituitary tumors and nontumorous pituitary was used for analysis of NG2 expression in the human adenohypophysis. The tissue used to create the TMA had been previously characterized for diagnostic purposes using histology and immunohistochemistry; electron microscopy was performed only when required for accurate subtyping. The TMA included triplicate cores of the following tumor types: 10 corticotrophs, 10 somatotrophs (5 each densely and sparsely granulated subtypes), 3 mixed GH-PRL or mammosomatotrophs, 4 sparsely granulated lactotroph, 1 acidophil stem cell, 1 thyrotroph, 2 plurihormonal Pit-1 lineage (silent subtype 3), 32 gonadotrophs, and 22 null cells. In addition, there was one pituitary with somatotroph hyperplasia. Cores of the liver and kidney were used for orientation. NG2 immunohistochemistry was performed on 4-micron sections mounted on coated slides using the affinitypurified rabbit antirecombinant rat NG2 ectodomain provided by Stallcup (Sanford Burnham Prebys Medical Discovery Institute, La Jolla, CA, USA) incubated at 1:500 dilution overnight after TE9 pretreatment.

\section{Immunofluorescence detection of NG2}

Snap-frozen tissue sections of normal mouse pituitaries were fixed in prechilled acetone $10 \mathrm{~min}$, washed with PBS, and blocked for $1 \mathrm{~h}$ at room temperature in 1\% BSA in PBS. Tissue sections were then stained with anti-NG2 antibody (Santa Cruz, SC-30921, at 1:100) overnight at room temperature. After PBS washes, sections were incubated with Alexa555-conjugated secondary antibody (Life Technologies). After PBS washes, samples were incubated with the pituitary hormone antibodies specified previously for $30 \mathrm{~min}$ at room temperature. After PBS washes, sections were incubated with Alexa488-conjugated secondary antibody (Life Technologies). Tissue sections were examined with two-photon microscope (LSM700, Zeiss) equipped with a $63 \times$ oil immersion objective lens and filters optimized for double-label experiments. Images were analyzed using the LSM IMAGE browser.

\section{Transmission electron microscopy}

For electron microscopy, small pieces of pituitary tumor tissue from the NG2creBAC:pRbflox/flox mice were fixed in $2.5 \%$ glutaraldehyde, postfixed in $1 \%$ osmium tetroxide, dehydrated in graded ethanols, processed through propylene oxide, and embedded in epoxy resin. Semi-thin sections were stained with toluidine blue, and appropriate areas were selected for the fine structural study. Ultrathin sections were stained with uranyl acetate and lead citrate and investigated with a JEOL JEM-1230 electron microscope (Akishima, Tokyo, Japan).

\section{Hormone assays}

Blood from mice was collected at the time of killing. Hormone assays were performed using the following ELISA kits: IGF1 Quantikine (R\&D Systems); PRL and TSH both from Calbiotech, Spring Valley, CA, USA.

\section{RNA extraction and semiquantitative reverse transcription (RT)-PCR}

Total RNA was isolated from human pituitary tissue using TRIzol reagents (Invitrogen). One microgram of total DNase-treated RNA from each sample was used to perform reverse transcription in a $20 \mu \mathrm{L}$ volume using TaqMan Reverse Transcription Reagents kit (Applied Biosystems). The synthesized cDNA was used for PCR amplification. RT-PCR primers were designed to span exons to avoid genomic DNA contamination. The primer sequences are as follows: NG2: 5'-GCC CTA CTT CCC CAC TCT CCT G-3' Rev: 5'-GCT GCT CTT CCA CCA TTC TCC A-3' to generate a 134 bp product; PGK1: Fwd: 5'-GCT GAC AAG TTT GAT GAG AAT-3'; Rev: 5'-AGG ACT TTA CCT TCC AGG AGC-3' to generate a 359 bp product.

\section{Cell lines and cultures}

Rat pituitary GH4 mammosomatotroph cells were propagated in Ham F10 medium supplemented with

Published by Bioscientifica Ltd 
$12.5 \%$ horse and $2.5 \%$ FBS (Sigma), $2 \mathrm{mM}$ glutamine, $100 \mathrm{IU} / \mathrm{mL}$ penicillin, and $100 \mu \mathrm{g} / \mathrm{mL}$ streptomycin $\left(37^{\circ} \mathrm{C}\right.$, 95\% humidity, 5\% $\mathrm{CO}_{2}$ atmosphere incubation).

\section{Plasmids and transfection}

Rat NG2 cDNA from the NG2 expression vector kindly gifted from Stallcup was subcloned into pcDNA3.1 expression vector. The NG2 expression vector or empty vector was stably transfected into GH4 cells using Lipofectamine 2000 (Life Technologies) according to the manufacturer's instructions. Stable clones were selected using neomycin (G418) at a concentration of $0.7 \mu \mathrm{g} / \mathrm{mL}$.

\section{Western blotting}

Cells were lysed in lysis buffer (0.5\% sodium deoxycholate, $0.1 \%$ sodium dodecyl sulfate, $1 \%$ Nonidet P-40 and $1 \times$ PBS) containing proteinase inhibitors $(100 \mu \mathrm{g} / \mathrm{mL}$ phenylmethylsulfonyl fluoride (PMSF), $13.8 \mu \mathrm{g} / \mathrm{mL}$ aprotinin (Sigma), and $1 \mathrm{mM}$ sodium orthovanadate (Sigma). Total cell lysates were incubated on ice for $30 \mathrm{~min}$, followed by microcentrifugation at $10,000 \mathrm{~g}$ for $10 \mathrm{~min}$ at $4^{\circ} \mathrm{C}$. Protein concentrations of the supernatants were determined by the Bio-Rad method. Equal amounts of protein (10 $\mathrm{gg})$ were mixed with $5 \times$ SDS sample buffer, boiled for $5 \mathrm{~min}$, and separated by 8 or $12 \%$ SDS-PAGE, and transferred onto PVDF membranes $(0.45 \mu \mathrm{m}$; Millipore). Intracellular and secreted hormones were determined using polyclonal antisera to PRL or GH (NHPP) applied at dilutions of 1:8000 and 1:50,000, respectively. Immunoblotting was performed using anti-NG2 (Millipore, 1:1000), antipY-STAT3 (Y705, 1:1000), STAT3 (1:2500), and tubulin (1:1000) (all from Cell Signaling). Nonspecific binding was blocked with $5 \%$ nonfat milk in $1 \times$ Tris-buffered saline (TBST with $0.1 \%$ Tween-20). After washing for $3 \times$ 10 min in $1 \times$ TBST, blots were exposed to the secondary antibody (anti-rabbit IgG-HRP, Santa Cruz) at a dilution of 1:2000 and were visualized using ECL chemiluminescence detection system (Amersham).

\section{Cell cycle analysis}

Equal numbers of GH4 cells were plated and synchronized with defined media for $24 \mathrm{~h}$, and then cultured with growth media for $24 \mathrm{~h}$. After trypsinization, $3 \times 10^{6}$ cells were washed with cold PBS and fixed with cold 70\% ethanol for $1 \mathrm{~h}$ on ice. Fixed cells were washed with staining buffer
(0.2\% Triton X-100 and $1 \mathrm{mM}$ EDTA (pH 8.0) in PBS) and resuspended in the staining buffer containing $50 \mu \mathrm{g} / \mathrm{mL}$ ribonuclease A (Sigma Chemical Co., St Louis, MO, USA) and $50 \mu \mathrm{g} / \mathrm{mL}$ propidium iodide for $1 \mathrm{~h}$. Cell cycle analysis was performed using flow cytometry (Becton Dickinson, San Jose, CA, USA).

\section{Adhesion assay}

GH4 cells were plated at $1 \times 10^{5}$ cells per well of Collagen IV-coated culture plates in triplicate and incubated for $4 \mathrm{~h}$, washed with PBS, and fixed and stained with Diff Quik kit (BD Biosciences) according to the manufacture's protocol. Images of entire wells were obtained with a stereomicroscope and were analyzed using the ImageJ Software (NIH, Bethesda, MD, USA) .

\section{Statistics}

Data are presented as mean \pm standard deviation (s.D.).

\section{Ethics statement}

The care of animals was approved by the Institutional Animal Care facilities. The use of human pituitary tissue was approved by the University Health Network Research Ethics Board.

\section{Results}

pRb inactivation in NG2-expressing cells leads to Pit1-lineage pituitary tumors

$\mathrm{pRb}$ inactivation is known to induce the development of poorly differentiated corticotroph tumors in the intermediate lobe of the mouse pituitary (Jacks et al. 1992). Abnormalities of the pituitary gland have not been described in global NG2 knockout mice (Chang et al. 2012, She et al. 2015). In marked contrast, here we show that targeted pRb inactivation in NG2-expressing cells results in striking pituitary tumor development in the anterior pituitary gland. Specifically, mice generated through NG2 promoter-driven Cre recombinase (NG2Cre) mice crossed with $p R b_{\text {flox/flox }}$ mice permitted the examination of the impact of $\mathrm{pRb}$ inactivation in NG2expressing cells. NG2-Cre:pRbflox/flox mice developed pituitary tumors with near complete penetrance (Table 1). Morphologic analysis of the pituitary glands from NG2-Cre:pRbflox/flox mice revealed early breakdown of the reticulin fiber network, the morphologic hallmark

Published by Bioscientifica Ltd 
Table 1 Summary of pituitary morphologic findings in NG2-Cre:pR $b^{\text {flox/flox }}$ mice.

\begin{tabular}{|c|c|c|c|c|c|c|c|c|c|}
\hline \multirow[b]{2}{*}{ ID } & \multirow[b]{2}{*}{ Sex } & \multirow[b]{2}{*}{ Age (days) } & \multirow[b]{2}{*}{ No tumor* } & \multirow[b]{2}{*}{ Tumor(s) } & \multicolumn{5}{|c|}{ Immunoprofile of tumor(s) } \\
\hline & & & & & Pit-1 & $\mathrm{GH}$ & PRL & $\alpha S U$ & $\beta \mathrm{TSH}$ \\
\hline 1 & $\mathrm{~F}$ & 126 & & Microadenoma x2 & 2 & 2 & & & 1 \\
\hline 2 & $\mathrm{~F}$ & 134 & No tumor & & & & & & \\
\hline 3 & $\mathrm{~F}$ & 153 & & Microadenoma x2 & 2 & 2 & & & 1 \\
\hline 4 & $\mathrm{~F}$ & 157 & No tumor & & & & & & \\
\hline 5 & $M$ & 175 & No tumor & & & & & & \\
\hline 6 & $\mathrm{~F}$ & 181 & & Microadenoma x2 & 2 & 2 & 2 & & 1 \\
\hline 7 & $\mathrm{~F}$ & 185 & & Microadenoma x3 & 3 & 3 & 3 & 3 & \\
\hline 8 & $\mathrm{~F}$ & 206 & & Microadenoma x2 & 2 & 2 & 2 & 2 & 1 \\
\hline 9 & $\mathrm{~F}$ & 226 & & Macroadenoma & 1 & 1 & 1 & 1 & \\
\hline 10 & M & 227 & & Macroadenoma & 1 & & 1 & 1 & \\
\hline 11 & $M$ & 238 & & Macroadenoma & 1 & & & 1 & \\
\hline 12 & $M$ & 240 & & Macroadenoma & 1 & & & 1 & \\
\hline 13 & $\mathrm{M}$ & 243 & No tumor & & & & & & \\
\hline 14 & $M$ & 243 & No tumor & & & & & & \\
\hline 15 & $\mathrm{M}$ & 243 & & Microadenoma & 1 & & & & 1 \\
\hline 16 & $\mathrm{~F}$ & 245 & & Macroadenoma & 1 & 1 & 1 & 1 & \\
\hline 17 & $\mathrm{~F}$ & 248 & & Macroadenoma & 1 & & 1 & & \\
\hline 18 & $M$ & 268 & & Macroadenoma & 1 & & & 1 & \\
\hline 19 & $\mathrm{~F}$ & 268 & & Macroadenoma & 1 & & & & \\
\hline 20 & $\mathrm{~F}$ & 271 & & Macroadenoma & 1 & & & & \\
\hline 21 & $\mathrm{~F}$ & 287 & & Macroadenoma & 1 & 1 & 1 & 1 & 1 \\
\hline 22 & $M$ & 289 & & Macroadenoma & 1 & 1 & 1 & 1 & 1 \\
\hline 23 & $\mathrm{~F}$ & 293 & & Macroadenoma & 1 & & 1 & & \\
\hline 24 & $\mathrm{~F}$ & 295 & & Macroadenoma & 1 & 1 & 1 & 1 & \\
\hline 25 & $\mathrm{~F}$ & 308 & & Macroadenoma & 1 & & & & \\
\hline 26 & $\mathrm{M}$ & 313 & & Microadenoma x4 & 4 & 2 & 2 & 4 & 1 \\
\hline 27 & $M$ & 313 & & Microadenoma x2 & 2 & 1 & & 1 & \\
\hline 28 & M & 313 & & Microadenoma & 1 & & 1 & 1 & 1 \\
\hline 29 & $\mathrm{M}$ & 326 & & Macroadenoma & 1 & 1 & & & \\
\hline 30 & $\mathrm{~F}$ & 335 & & Macroadenoma & 1 & & & 1 & \\
\hline 31 & $\mathrm{~F}$ & 337 & & Macroadenoma & 1 & 1 & & 1 & 1 \\
\hline 32 & $\mathrm{~F}$ & 337 & & Macroadenoma & 1 & & & 1 & \\
\hline 33 & $\mathrm{M}$ & 340 & & Macroadenoma & 1 & & & 1 & \\
\hline 34 & $\mathrm{M}$ & 355 & & Macroadenoma & 1 & & 1 & 1 & \\
\hline 35 & $\mathrm{~F}$ & 357 & & Macroadenoma & 1 & & 1 & 1 & \\
\hline 36 & $\mathrm{M}$ & 359 & & Macroadenoma x2 & 2 & 1 & & 2 & 1 \\
\hline 37 & $\mathrm{M}$ & 370 & & Macroadenoma & 1 & 1 & & 1 & 1 \\
\hline 38 & $\mathrm{M}$ & 373 & & Macroadenoma & 1 & & 1 & 1 & \\
\hline 39 & $\mathrm{~F}$ & 375 & & Macroadenoma & 1 & 1 & 1 & 1 & 1 \\
\hline 40 & $M$ & 408 & & Macroadenoma & 1 & 1 & 1 & 1 & 1 \\
\hline 41 & $\mathrm{~F}$ & 423 & & Macroadenoma & 1 & 1 & 1 & 1 & \\
\hline 42 & $\mathrm{~F}$ & 426 & & Macroadenoma x2 & 2 & 1 & 1 & 1 & \\
\hline 43 & $\mathrm{~F}$ & 470 & & Macroadenoma & 1 & & & & \\
\hline 44 & $\mathrm{M}$ & 484 & & Macroadenoma & 1 & & 1 & 1 & \\
\hline 45 & $\mathrm{M}$ & 547 & & Macroadenoma & 1 & 1 & & 1 & 1 \\
\hline
\end{tabular}

of true neoplasia. This was often multifocal and bilateral in the anterior pituitary glands starting at 4-5 months of age (Fig. 1A). Tumor growth was evident with increasing age; at 7-8 months, tumors were obvious within the pituitaries (Fig. 1B), and by 1 year of age, all mice developed large tumors (Fig 1C and D) that compressed the surrounding brain structures, including the optic chiasm, with symptoms of head tilt, including cerebellar ataxia. There was no evidence of malignancy as there was no metastasis found at complete autopsy.

The tumors were composed of solid sheets, nests and trabecula of well-differentiated epithelial cells within a fibrovascular stroma; there was prominent peliosis (Fig. 2A). Immunohistochemistry proved that the pituitary neoplasms were uniformly positive for the transcription factor Pit1 (Fig. 2A), with some showing

Published by Bioscientifica Ltd 
A

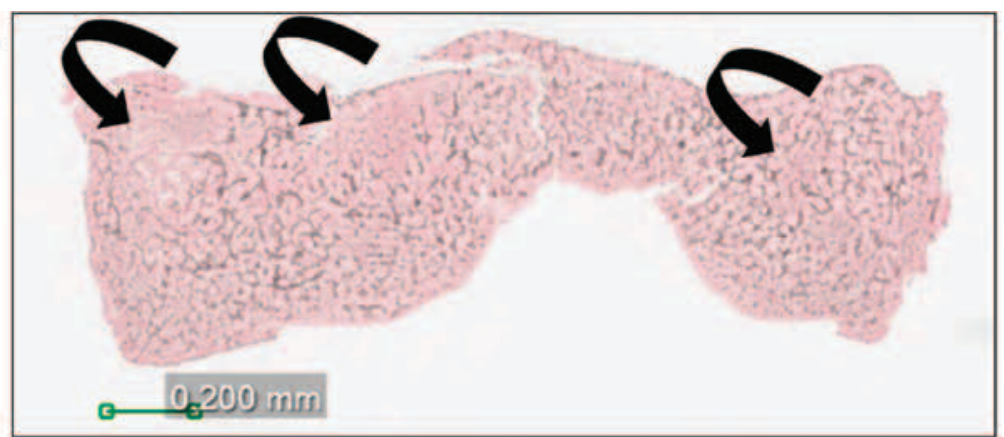

B

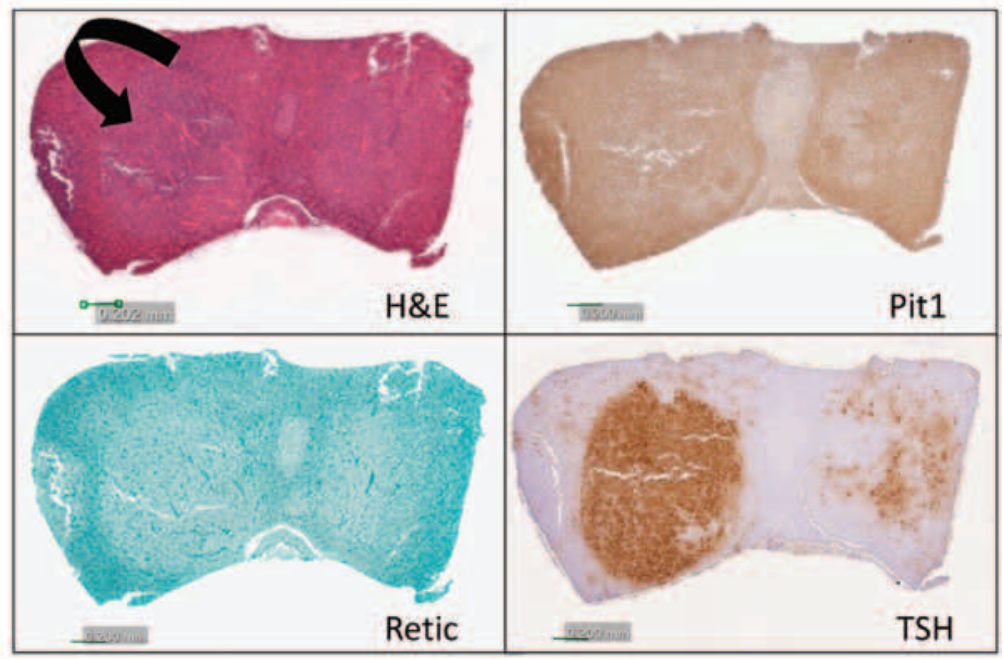

C

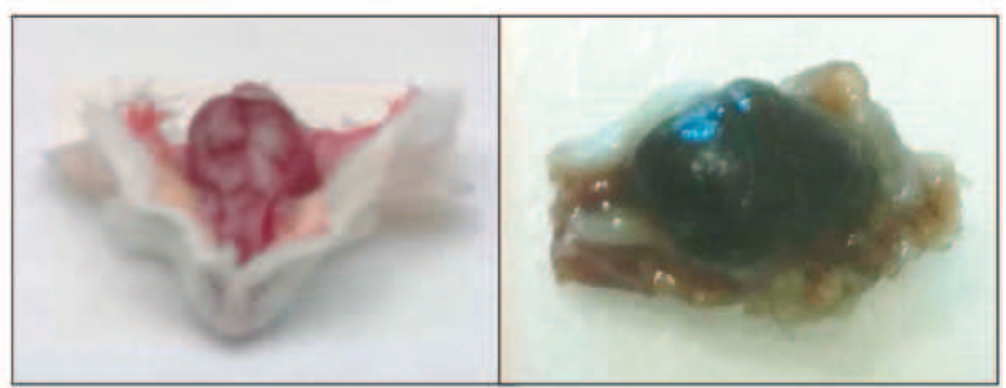

D

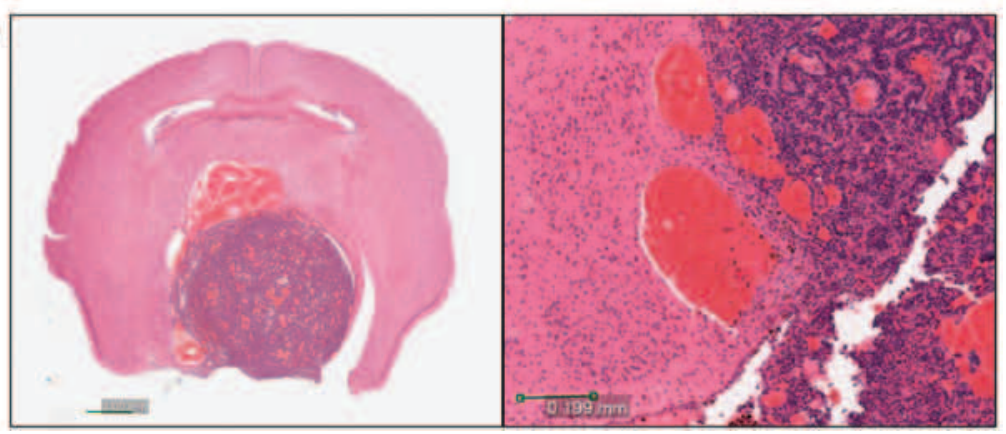

\section{Figure 1}

pRb inactivation in NG2-Cre:pRb floxfflox mice leads to pituitary tumors. (A) The anterior pituitary gland of a female mouse sacrificed at 157 days of age shows multifocal breakdown of the reticulin fiber network (arrows). (B) At 7-8 months, tumors were obvious within the pituitaries; this pituitary of a male mouse sacrificed at 243 days of age contains a large tumor that is evident on the hematoxylin and eosin stain and seen easily in the reticulin stain, expresses nuclear Pit1 as do the majority of cells in the nontumorous pituitary, and also expresses TSH. (C) Mice with large pituitary tumors in this cohort exhibited congestion of the brain (left). After removal of the overlying brain of this 373-day-old mouse, a large but well-delineated and grossly hemorrhagic tumor is seen emerging from the sella turcica (right). (D) A whole mount section of the tumor in a female mouse at age 245 days; the pituitary tumor expands upward, compressing the brain and ventricles (left). Infiltration of brain parenchyma is seen on higher magnification of a pituitary tumor from a male mouse at age 289 days (right). positivity for ER $\alpha$, but no positivity for SF1 or ACTH. The Pit1-positive tumors showed variable expression of GH, PRL, TSH, and $\alpha \mathrm{SU}$ (Fig. 2A). As expected, they were negative for $\mathrm{Rb}$ (Supplementary Fig. 1, see section on supplementary data given at the end of this article). In some animals, there was clear evidence of multiple lesions (Fig. 2B); in older animals with large tumors, variable immunoprofiles suggested that multiple tumors had grown together as collision tumors. The most common lesions were plurihormonal, expressing $\mathrm{GH}$, PRL, $\alpha \mathrm{SU}$, and TSH in various combinations (Fig. $2 \mathrm{~A}$ and Supplementary Fig. 2). Only a few tumors expressed only

Published by Bioscientifica Ltd 
A
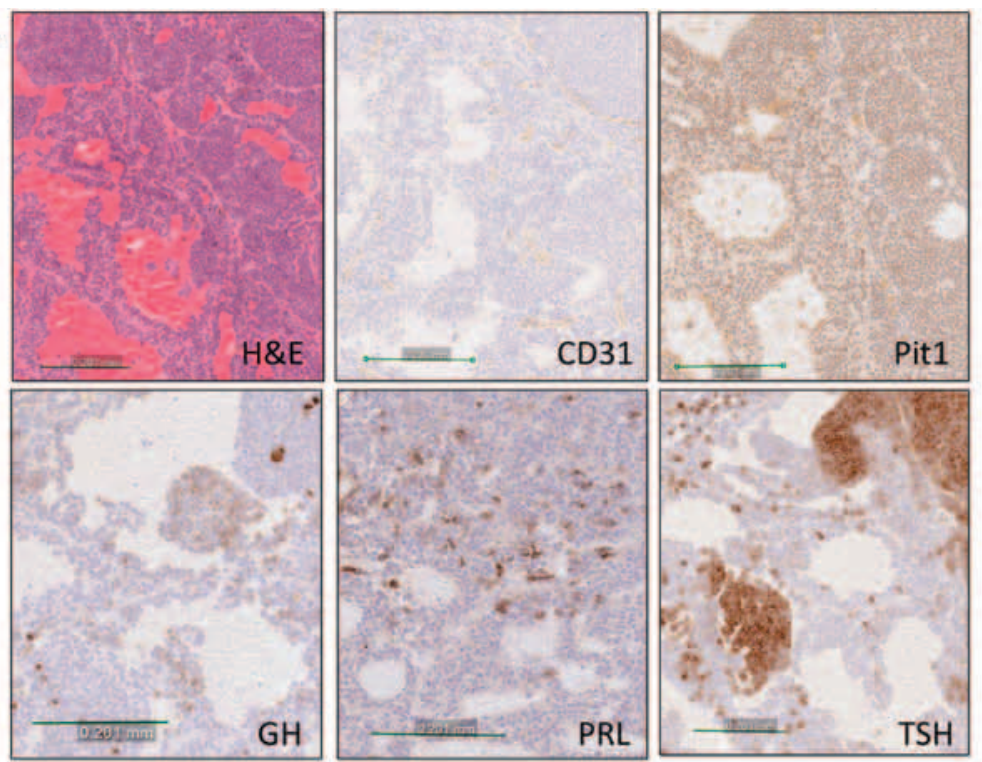

B
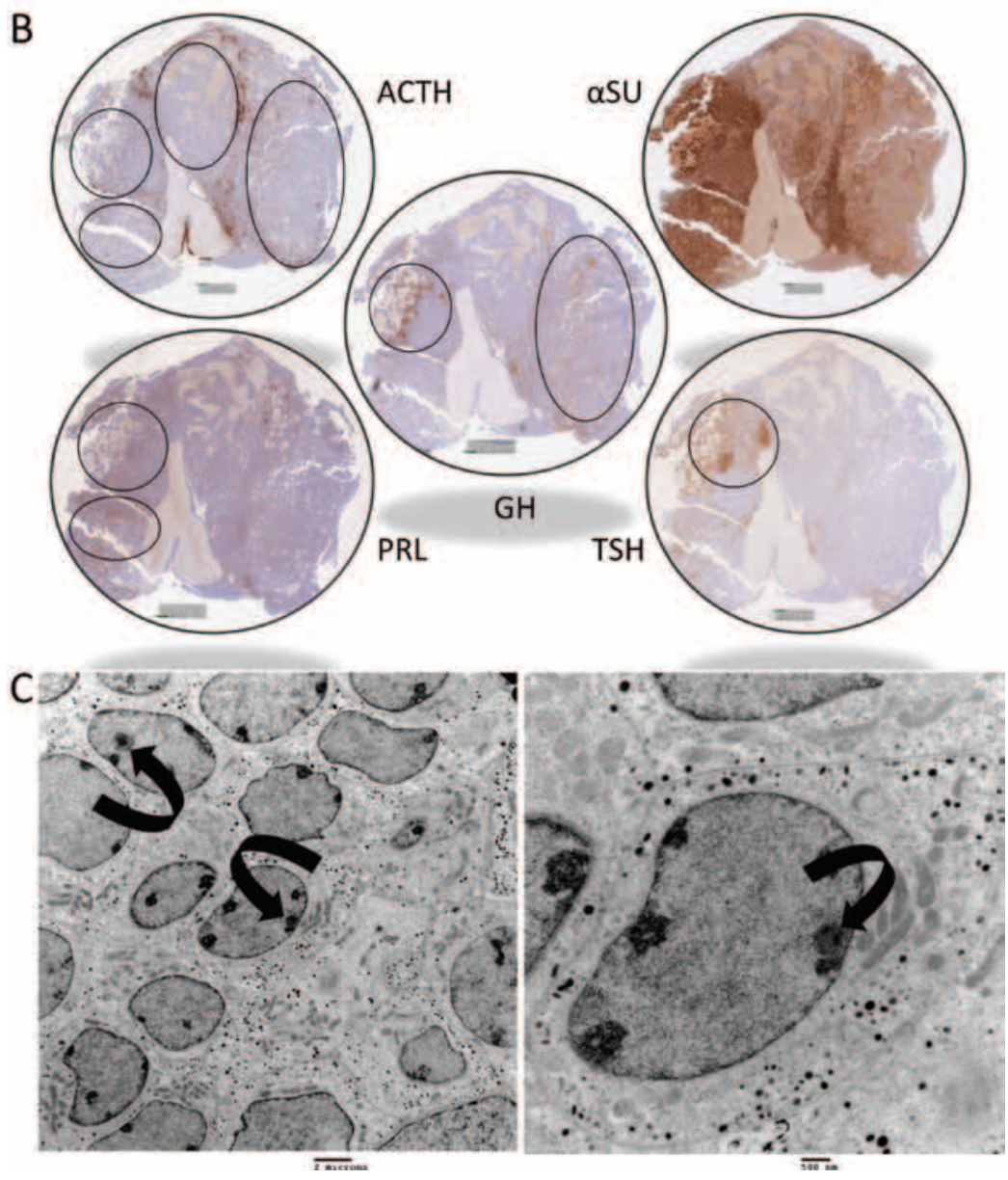

Figure 2

NG2-Cre:pRb flox/flox mice develop multifocal tumors of Pit1 lineage. (A) The tumors of NG2-Cre:pR $b^{\text {floxkflox }}$ mice show peliosis that lacks staining for CD31. The tumors were uniformly positive for the transcription factor Pit1 and had variable expressions of GH, PRL, and TSH. (B) Different immunoprofiles confirm the existence of multiple tumors that displace the normal gland decorated by ACTH staining; all four tumors stain for $\alpha \mathrm{SU}$, two for GH, two for PRL, and one for TSH. (C) By electron microscopy, the tumors are composed of monomorphous populations of round to polygonal epithelial cells with nuclear spheridia (arrows), well-developed rough endoplasmic reticulum and Golgi complexes, and membrane-bound secretory granules predominantly at the cell membrane. Higher magnification (right) shows these subcellular features in greater detail.
$\mathrm{GH}$ with or without $\alpha \mathrm{SU}$, consistent with somatotroph differentiation; a small number were prolactinomas with PRL positivity only; and occasional tumors produced only TSH and $\alpha \mathrm{SU}$, indicating thyrotroph differentiation.
Electron microscopy of the plurihormonal tumors confirmed that they were composed of uniform populations of round to polygonal epithelial cells with irregular nuclei harboring spheridia, abundant

Published by Bioscientifica Ltd 
rough endoplasmic reticulum, Golgi complexes, and occasional lysosomes, and forming membrane-bound secretory granules that were somewhat variable but were predominantly small and lined up along the cell membrane (Fig. 2C).

Among 12 heterozygous NG2-Cre:pRbflox/+ mice maintained for up to 537 days, only one mouse developed a pituitary tumor. This 537-day-old female had a Pit1-lineage tumor that expressed PRL, $\alpha \mathrm{SU}$, and TSH.

\section{Pit1-lineage tumors in NG2-Cre:pRb flox/flox mice do not cause hormone excess}

As most of the pituitary tumors from the knockout mice developed hormone-producing tumors of Pit1 lineage, we examined their functionality in vivo. The NG2-Cre:pRbflox/flox mice did not exhibit an increase in body size or an acromegalic appearance. Moreover, serum IGF-1 levels were not higher in transgenic mice than in age-matched control littermates (Fig. 3A). Serum PRL ranged from 3 to $129.39 \mathrm{ng} / \mathrm{mL}$ (average $34 \mathrm{ng} / \mathrm{mL}$ ), whereas it ranged from 2.9 to $24.95 \mathrm{ng} / \mathrm{mL}$ in wild-type animals; the elevated levels may be attributed to tumor production but can also be explained by stalk section effect. We could not measure TSH levels in the circulation. By the end point, NG2-Cre:pRbflox/flox mice were thinner and weaker due to reduced food intake and had lower serum IGF-1 levels compared with their age-matched control littermates (Fig. 3A).

\section{NG expression in the pituitary gland and pituitary tumors}

NG2 has been reported to be expressed on the surface of a variety of cell types, including oligodendrocyte progenitor cells, chondroblasts, myoblasts, and pericytes, as well as in cancers such as glioblastoma and melanoma. However, its expression in the pituitary gland has not been reported. Given the development of tumors in the NG2-Cre:pRbfloxflox mice, we first investigated NG2 expression in the mouse pituitary gland by immunohistochemistry. NG2 immunoreactivity was identified in the anterior and posterior lobes of the gland but not in the intermediate lobe (Fig. 4A). NG2 immunoreactivity was strongest in the sustentacular folliculostellate cells, but was also seen weakly and focally in adenohypophysial cells (Fig. 4A). Using immunofluorescence, NG2 immunoreactivity was colocalized in cells expressing nuclear Pit1 and in the various Pit1-lineage cells, including GH-producing somatotrophs, PRL-producing lactotrophs, and TSH-producing thyrotrophs (Fig. 4B). By contrast, NG2 did not colocalize with gonadotropins or with ACTH immunoreactivity; undetectable expression in corticotrophs explains the lack of expression in the intermediate lobe, which is exclusively composed of corticotrophs in the mouse.

Next we examined NG2 gene expression in human pituitaries. By RT-PCR, we identified NG2 expression in normal human pituitary glands as well as in various types of human pituitary adenohypophysial tumors (Fig. 4C). However, the expression of NG2 by RT-PCR in human pituitary tissues may be a reflection of the common presence of folliculostellate cells. Therefore, immunohistochemistry was performed. This confirmed staining in the majority of cells of the nontumorous adenohypophysis, most intensely in folliculostellate cells (Fig. 4A); of 85 adenohypophysial tumors and 1 somatotroph hyperplasia, all 10 corticotroph tumors were negative, and the strongest positivity was found in tumors of Pit1 lineage ( 8 of 10 somatotrophs, 2 of 3 mixed or mammosomatotrophs, 4 lactotrophs, 1 acidophil stem cell, 1 thyrotroph, and 2 plurihormonal Pit1-lineage tumors). There was also variable positivity in 32 gonadotrophs and 22 null cell tumors.

\section{NG2 alters hormone production and adhesion but not cell cycle in adenohypophysial cells}

Having identified the expression of NG2 in nontumorous and transformed adenohypophysial cells, we examined

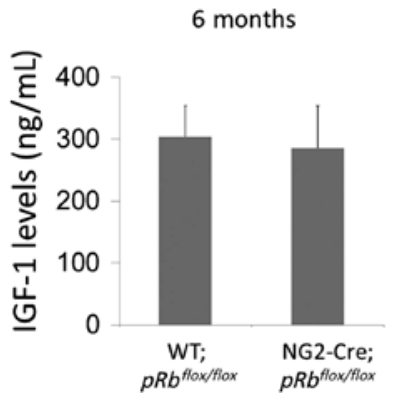

http://erc.endocrinology-journals.org DOI: 10.1530/ERC-16-0013

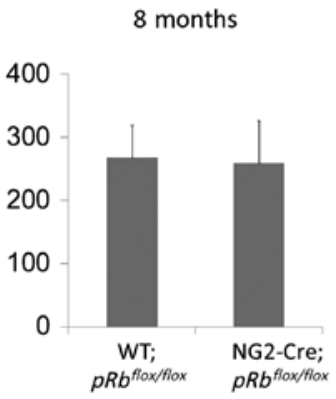

(C) 2016 Society for Endocrinology Printed in Great Britain
Endpoint

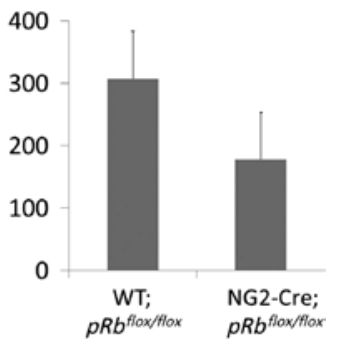

Figure 3

Pit1-lineage tumors in NG2-Cre:pRb flox/flox mice do not cause hormone excess. IGF-1 levels were not different in control and NG2-Cre:pR $b^{\text {flox/flox }}$ mice at 6 or 8 months; by the end point when the animals had large tumors, the NG2-Cre:pR $b^{\text {flox } / \text { flox mice }}$ had lower IGF-1 levels associated with tumor-associated wasting. 
A

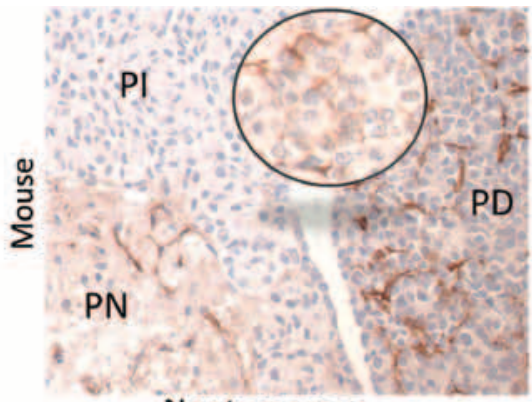

Nontumorous

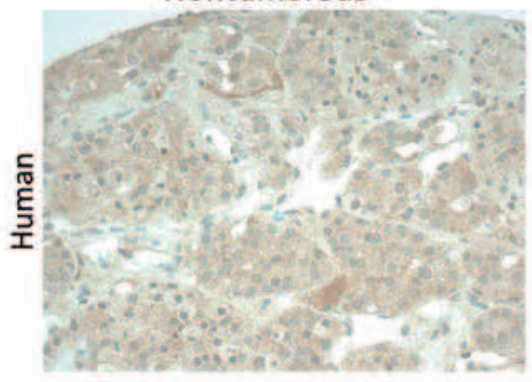

B

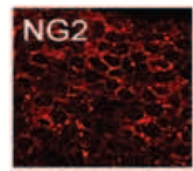

NG2.

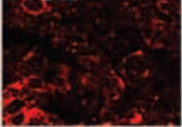

NG2
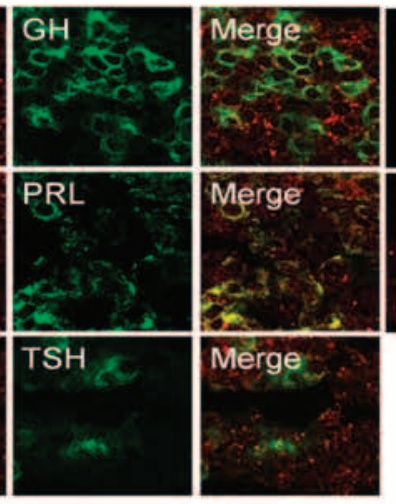

Merge
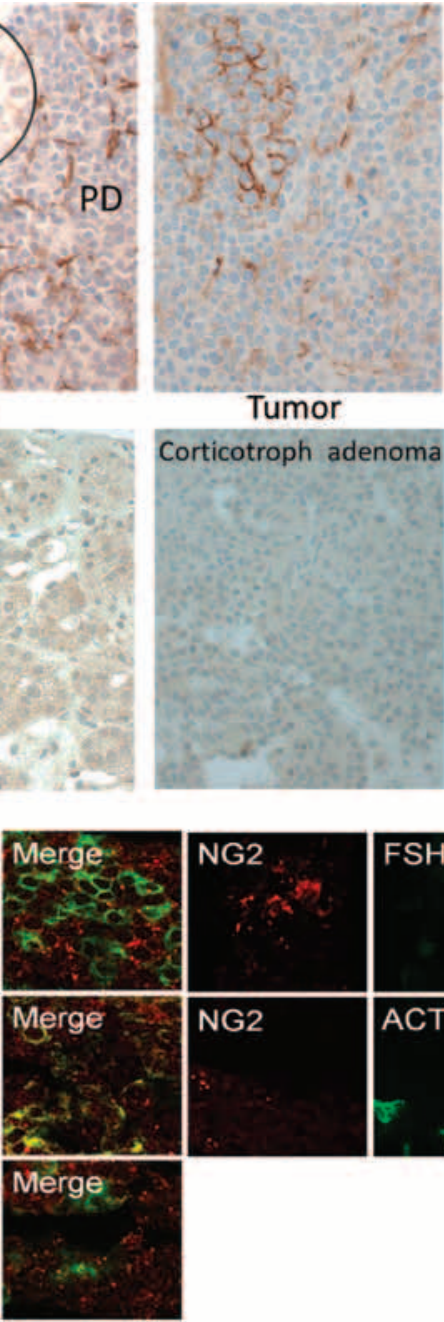

Tumor
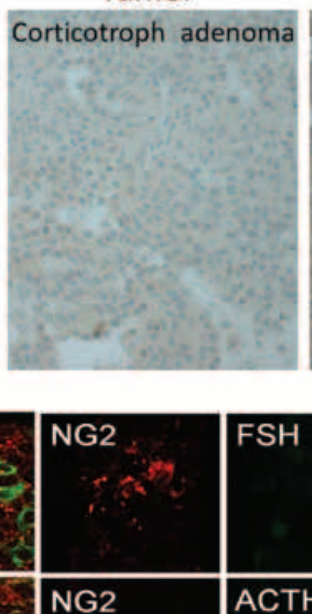

NG2
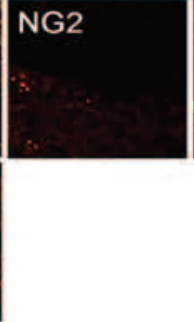

C

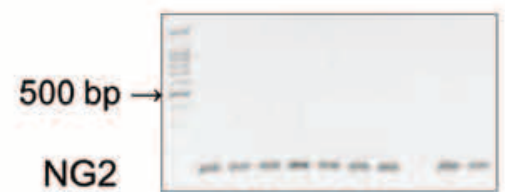

$1234567 \quad 89$

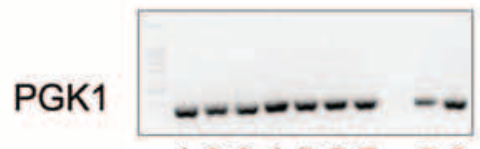

$1234567 \quad 89$

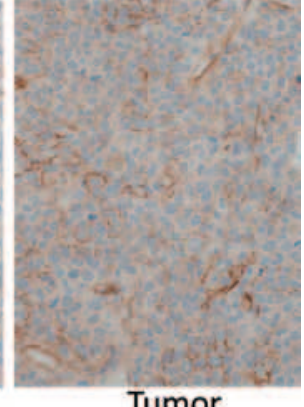

Tumor
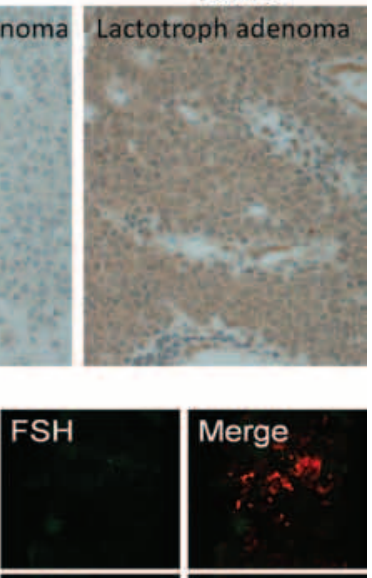

ACTH
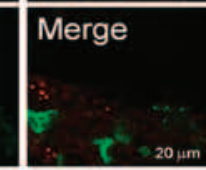

7

\section{Figure 4}

NG2 expression in the pituitary gland and pituitary tumors. (A) Immunohistochemistry for NG2 in the normal mouse pituitary (top row left) reveals strong reactivity in the anterior lobe (pars distalis (PD)) and posterior lobe (pars nervosa (PN)) but not in the intermediate lobe (pars intermedia (PI)). In the anterior lobe, the immunoreactivity for NG2 is identified strongly in folliculostellate (FS) cells but also in adenohypophysial cells (inset). Two examples of pituitary tumors from NG2-Cre: $p R b^{\text {floxfllox }}$ mice stain for NG2 (top row, center and right). In the human adenohypophysis (bottom row), the normal gland exhibits diffuse positivity that is strongest in FS cells (left); corticotroph neoplasms were generally negative (center), whereas other tumor types exhibit variable positivity. (B) In normal mouse pituitary, immunofluorescence identifies NG2 immunoreactivity (red) that colocalizes with GH, PRL, and TSH (green), seen as yellow in the merged images. No colocalization was seen with FSH or ACTH. (C) RT-PCR shows NG2 and PGK1 expression in normal human pituitary (lanes 8 and 9) as well as pituitary tumors (lanes 1 and 4: gonadotroph; lanes 2 and 3: lactotroph; lane 5: silent corticotroph; lanes 6 and 7: somatotroph). the functional role of NG2 using mammosomatotroph cells that are of Pit1 lineage and coexpress PRL and GH. As GH4 cells do not express endogenous NG2, we established GH4 cells stably expressing NG2. This NG2 expression increased pY-STAT3 levels associated with PRL induction and diminished GH expression (Fig. 5A). NG2 enhanced GH4 cell adhesion (Fig. 5B) but had no detectable impact on cell proliferation (data not shown).

\section{Discussion}

The development of pituitary adenohypophysial tumors in NG2-Cre:pRbflox/flox mice was an unexpected finding, because NG2 was not known to be expressed in the pituitary. Interestingly, the tumors in this mouse model represent the closest mimic to human pituitary tumors in mice with loss of cell cycle regulators. Apart from 
menin-deficient mice that model multiple endocrine neoplasia with pituitary tumor formation (Crabtree et al. 2001), most other mouse models, including $\mathrm{pRb}$, p27, and p18 knockout mice, develop highly aggressive tumors that usually arise from the intermediate lobe, a structure that is important in rodents but is vestigial in humans (Asa 2001).

$\mathrm{Rb}$ signaling is known to be critical in adenohypophysial cell homeostasis, and although Rb mutation is not a feature of human pituitary tumors, epigenetic silencing has been implicated in dysregulated expression of this tumor suppressor (Yoshino et al. 2007). Targeted silencing of $\mathrm{Rb}$ by NG2 resulted in adenohypophysial tumors with immunohistochemical and ultrastructural features that resemble those of aggressive Pit1-lineage tumors in humans, previously called 'silent subtype 3 adenomas' (Mete et al. 2016). These tumors are composed of cells that exhibit Pit1-lineage differentiation, but they are not differentiated somatotrophs, mammosomatotrophs,

A

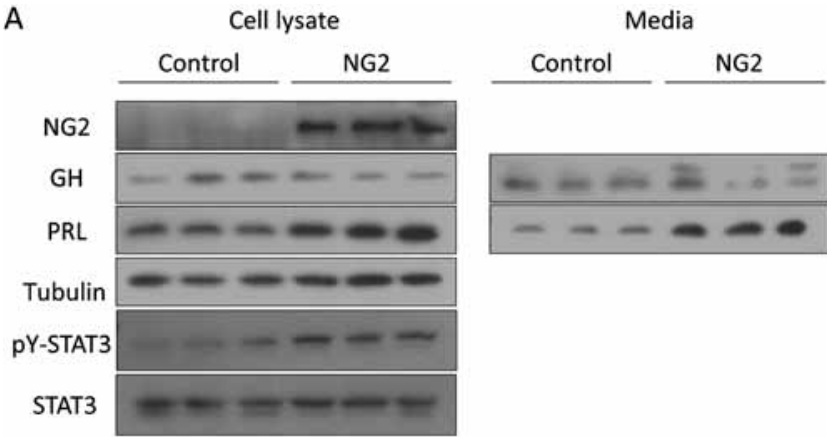

B

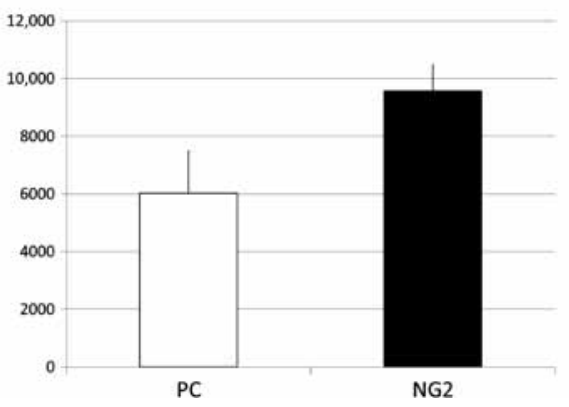

Figure 5

NG2 alters hormone production and adhesion in adenohypophysial cells. (A) Stable NG2 expression in GH4 mammosomatotroph cells increased PRL and reduced GH expression in both cell lysates (left) and media (right); tubulin served as a loading control for cell lysates. These changes were associated with increased pY-STAT3 levels, whereas total STAT3 was unchanged. Each lane represents an independent clone. (B) NG2 enhanced GH4 cell adhesion (number of adherent cells). GH4 cells were allowed to adhere to Collagen IV-coated plates in triplicates as detailed in the 'Materials and methods' section. Values represent the mean \pm s.D. of cell numbers captured by software image analysis of entire wells. lactotrophs, or thyrotrophs; they most closely resemble thyrotrophs (Mete et al. 2016). As the original name suggests, these tumors are usually not associated with florid hormone excess in humans, similar to what we identified in the current mouse model. The reasons for this lack of consistent hormone hypersecretory phenotype and/or biochemical evidence of hormone excess are not clear. It is not likely to be attributed to $\mathrm{Rb}$ dysregulation, because human tumors with $\mathrm{Rb}$ silencing show no preferential lack of functionality (Yoshino et al. 2007). It may be due to abnormal regulation of hormone synthesis and secretion, as is thought to be the case in most gonadotroph tumors (Snyder 1987, Asa et al. 1988, Penabad et al. 1996), or to abnormal processing of prohormone products, as has been suggested for silent corticotroph tumors (Lloyd et al. 1990, Chabre et al. 1991, Stefaneanu et al. 1991). However, as these two examples indicate, there is no strict relationship between hormone functionality and tumor aggressiveness, because silent gonadotroph tumors are not thought to be aggressive (Nishioka et al. 2015), whereas other silent neoplasms, including those of Pit1 lineage and silent corticotroph tumors, can be highly invasive and lack responsiveness to conventional therapies (Asa \& Ezzat 2016).

The development of these tumors in our mice prompted examination of the expression and functions of NG2 in the adenohypophysis. NG2 is strongly expressed in pituitary folliculostellate cells and less so in adenohypophysial cells of Pit1 lineage that express GH, PRL, and TSH. NG2 expression in the normal mouse is weak and focal in adenohypophyseal cells, thus, unlike the global loss of $\mathrm{Rb}$ resulting in intermediate lobe corticotroph tumors (Jacks et al. 1992), NG2-directed loss of $\mathrm{Rb}$ is restricted to anterior pituitary cells. It is this restricted and limited loss of $\mathrm{Rb}$ that likely also explains the lack of phenotype in most of the heterozygous $\mathrm{NG} 2-\mathrm{Rb}$ animals.

To carry out the functional studies of NG2 in the adenohypophysis, we stably expressed NG2 in GH4 mammosomatotroph cells, which are endogenously deficient of this proteoglycan. These studies revealed that NG2 enhances cell adhesion in those cells but had no discernible impact on cell proliferation. Interestingly, NG2 had a modest effect on hormone expression, resulting in an increase in PRL and diminished GH. The preliminary studies shown here suggest that this hormonal effect is, at least partially, mediated through STAT3 activation. As shown previously, STAT3 is a recognized switch serving to activate PRL gene 
expression while attenuating GH production in Pit1lineage mammosomatrophs (Tateno et al. 2011).

The role of folliculostellate cells in the pituitary has been the subject of long-standing controversy and speculation. Several years ago, it was suggested that spindle cell oncocytomas represent the long-anticipated tumor of folliculostellate cytogenesis (Roncaroli et al. 2002); however, these have now been shown to be derived from pituicytes of the posterior lobe (Mete et al. 2013). The strong expression of NG2 in folliculostellate cells of the adenohypophysis noted in our study is consistent with the recent description of NG2 expression in the clonal TtT cell line that is thought to be derived from folliculostellate cells (Yoshida et al. 2014). Nevertheless, it was quite unexpected that we found no evidence of proliferation or transformation of those cells in the mouse model. Instead, we propose that folliculostellate cells appear to be uniquely protected from the impact of $\mathrm{Rb}$ loss. His finding may explain why tumors from this cell lineage do not occur in mouse or man. This mouse model reemphasizes that, at the very least, loss of $\mathrm{pRb}$ is insufficient to result in transformation of folliculostellate cells; the factors underlying this protection from loss of $\mathrm{Rb}$ remain to be elucidated.

In sum, $\mathrm{pRb}$ inactivation in NG2-positive cells results in Pit1-lineage anterior pituitary tumors that closely mimic their human counterpart. They represent a novel mouse model for an aggressive pituitary tumor and can be used for further research, including preclinical testing of novel therapies.

\section{Supplementary data}

This is linked to the online version of the paper at http://dx.doi.org/10.1530/ ERC-16-0013.

\section{Declaration of interest}

The authors have no conflict of interest that could be perceived as prejudicing the impartiality of the research reported.

\section{Funding}

This work was funded by the CIHR (Grant MOP 79340) and the John and Myrna Daniels Endocrine Cancer Research Fund.

\section{Acknowledgments}

The mice used in this study were generously provided by Benjamin Alman, Hospital for Sick Children, Toronto, Ontario, Canada. The authors thank Shingo Sato for his assistance in the initial studies. They also thank the staff of the Pathology Research Program Laboratory for immunohistochemical stains and Lucy Andrighetti for electron microscopy. The authors acknowledge Bradly Wouters, Vuk Stambolic, and Fei-Fei Liu for their careful review and input to this manuscript.

\section{References}

Agustsson TT, Baldvinsdottir T, Jonasson JG, Olafsdottir E, Steinthorsdottir V, Sigurdsson G, Thorsson AV, Carroll PV, Korbonits M \& Benediktsson R 2015 The epidemiology of pituitary adenomas in Iceland, 1955-2012: a nationwide population-based study. European Journal of Endocrinology 173 655-664. (doi:10.1530/ EJE-15-0189)

Asa SL 2001 Transgenic and knockout mouse models clarify pituitary development, function and disease. Brain Pathology 11 371-383.

Asa SL 2011 Tumors of the pituitary gland. In AFIP Atlas of Tumor Pathology, Series 4, Fascicle 15, Silver Spring, MD, USA: ARP Press.

Asa SL \& Ezzat S 2009 The pathogenesis of pituitary tumors. Annual Review of Pathology 4 97-126. (doi:10.1146/annurev.pathol.4.110807.092259)

Asa SL \& Ezzat S 2014 Genomic approaches to problems in pituitary neoplasia. Endocrine Pathology 25 209-213. (doi:10.1007/s12022-0139276-5)

Asa SL \& Ezzat S 2016 Aggressive pituitary tumors or localized pituitary carcinomas: defining pituitary tumors. Expert Reviews Endocrinology and Metabolism 11 149-162. (doi:10.1586/17446651.2016.1153422)

Asa SL, Gerrie BM, Kovacs K, Horvath E, Singer W, Killinger DW \& Smyth HS 1988 Structure-function correlations of human pituitary gonadotroph adenomas in vitro. Laboratory Investigation 58 403-410.

Chabre O, Martinie M, Vivier J, Eimin-Richard E, Bertagna X \& Bachelot I 1991 A clinically silent corticotrophic pituitary adenoma (CSCPA) secreting a biologically inactive but immunoreactive assayable ACTH. Journal of Endocrinological Investigation 14 (Supplement 1) 87.

Chang Y, She ZG, Sakimura K, Roberts A, Kucharova K, Rowitch DH \& Stallcup WB 2012 Ablation of NG2 proteoglycan leads to deficits in brown fat function and to adult onset obesity. PLOS ONE 7 e30637. (doi:10.1371/journal.pone.0030637)

Crabtree JS, Scacheri PC, Ward JM, Garrett-Beal L, Emmert-Buck MR, Edgemon KA, Lorang D, Libutti SK, Chandrasekharappa SC, Marx SJ, et al. 2001 A mouse model of multiple endocrine neoplasia, type 1, develops multiple endocrine tumors. PNAS 98 1118-1123.

Daly AF, Rixhon M, Adam C, Dempegioti A, Tichomirowa MA \& Beckers A 2006 High prevalence of pituitary adenomas: a crosssectional study in the province of Liege, Belgium. Journal of Clinical Endocrinology and Metabolism 91 4769-4775. (doi:10.1210/jc.20061668)

Ezzat S, Asa SL, Couldwell WT, Barr CE, Dodge WE, Vance ML \& McCutcheon IE 2004 The prevalence of pituitary adenomas: a systematic review. Cancer 101 613-619. (doi:10.1002/cncr.20412)

Fernandez A, Karavitaki N \& Wass JA 2009 Prevalence of pituitary adenomas: a community-based, cross-sectional study in Banbury (Oxfordshire, UK). Clinical Endocrinology 72 377-382. (doi:10.1111/j.1365-2265.2009.03667.x)

Fontana E \& Gaillard R 2009 Epidemiology of pituitary adenoma: results of the first Swiss study. Revue Médicale Suisse 5 2172-2174.

Fukushi J, Inatani M, Yamaguchi Y \& Stallcup WB 2003 Expression of NG2 proteoglycan during endochondral and intramembranous ossification. Developmental Dynamics 228 143-148. (doi:10.1002/ dvdy.10359)

Jacks T, Fazeli A, Schmitt EM, Bronson RT, Goodell MA \& Weinberg RA 1992 Effects of an $R b$ mutation in the mouse. Nature 359 295-300. (doi:10.1038/359295a0)

Levine JM \& Nishiyama A 1996 The NG2 chondroitin sulfate proteoglycan: a multifunctional proteoglycan associated with immature cells. Perspectives on Developmental Neurobiology 3 245-259.

Lloyd RV, Fields K, Jin L, Horvath E \& Kovacs K 1990 Analysis of endocrine active and clinically silent corticotropic adenomas by in situ hybridization. American Journal of Pathology 137 479-488.

Mete O, Lopes MB \& Asa SL 2013 Spindle cell oncocytomas and granular cell tumors of the pituitary are variants of pituicytoma.

Published by Bioscientifica Ltd 
American Journal of Surgical Pathology 37 1694-1699. (doi:10.1097/ PAS.0b013e31829723e7)

Mete O, Gomez-Hernandez K, Kucharczyk W, Ridout R, Zadeh G, Gentili F, Ezzat S \& Asa SL 2016 Silent subtype 3 pituitary adenomas are not always silent and represent poorly differentiated monomorphous plurihormonal Pit-1 lineage adenomas. Modern Pathology 29 131-142. (doi:10.1038/modpathol.2015.151)

Nishioka H, Inoshita N, Mete O, Asa SL, Hayashi K, Takeshita A, Fukuhara N, Yamaguchi-Okada M, Takeuchi Y \& Yamada S 2015 The Complementary role of transcription factors in the accurate diagnosis of clinically nonfunctioning pituitary adenomas. Endocrine Pathology 26 349-355. (doi:10.1007/ s12022-015-9398-z)

Penabad JL, Bashey HM, Asa SL, Haddad G, Davis KD, Herbst AB, Gennarelli TA, Kaiser UB, Chin WW \& Snyder PJ 1996 Decreased follistatin gene expression in gonadotroph adenomas. Journal of Clinical Endocrinology and Metabolism 81 3397-3403.

Petrini S, Tessa A, Carrozzo R, Verardo M, Pierini R, Rizza T \& Bertini E 2003 Human melanoma/NG2 chondroitin sulfate proteoglycan is expressed in the sarcolemma of postnatal human skeletal myofibers. Abnormal expression in merosin-negative and Duchenne muscular dystrophies. Molecular and Cellular Neuroscience 23 219-231. (doi:10.1016/S1044-7431(03)00033-2)

Roncaroli F, Scheithauer BW, Cenacchi G, Horvath E, Kovacs K, Lloyd RV, Abell-Aleff P, Santi M \& Yates AJ 2002 'Spindle cell oncocytoma' of the adenohypophysis: a tumor of folliculostellate cells? American Journal of Surgical Pathology 26 1048-1055. (doi:10.1097/00000478-200208000-00010)

Sakry D, Neitz A, Singh J, Frischknecht R, Marongiu D, Biname F, Perera SS, Endres K, Lutz B, Radyushkin K, et al. 2014 Oligodendrocyte precursor cells modulate the neuronal network by activity-dependent ectodomain cleavage of glial NG2. PLoS Biology 12 e1001993. (doi:10.1371/journal.pbio.1001993)

She ZG, Chang Y, Pang HB, Han W, Chen HZ, Smith JW \& Stallcup WB 2015 NG2 ablation reduces low-density lipoprotein retention of synthetic smooth muscle cells and atherogenesis. Arteriosclerosis,
Thrombosis, and Vascular Biology 36 49-59. (doi:10.1161/ ATVBAHA.115.306074)

Snyder PJ 1987 Gonadotroph cell pituitary adenomas. Endocrinology and Metabolism Clinics of North America 16 755-764.

Stefaneanu L, Kovacs K, Horvath E \& Lloyd RV 1991 In situ hybridization study of pro-opiomelanocortin (POMC) gene expression in human pituitary corticotrophs and their adenomas. Virchows Archiv A: Pathological Anatomy and Histopathology 419 107-113. (doi:10.1007/BF01600224)

Tateno T, Asa SL, Zheng L, Mayr T, Ullrich A \& Ezzat S 2011 The FGFR4G388R polymorphism promotes mitochondrial STAT3 serine phosphorylation to facilitate pituitary growth hormone cell tumorigenesis. PLoS Genetics 7 e1002400. (doi:10.1371/journal. pgen.1002400)

Tjornstrand A, Gunnarsson K, Evert M, Holmberg E, Ragnarsson O, Rosen T \& Filipsson NH 2014 The incidence rate of pituitary adenomas in western Sweden for the period 2001-2011. European Journal of Endocrinology 171 519-526. (doi:10.1530/EJE-14-0144)

Wang J, Svendsen A, Kmiecik J, Immervoll H, Skaftnesmo KO, Planaguma J, Reed RK, Bjerkvig R, Miletic H, Enger PO, et al. 2011 Targeting the NG2/CSPG4 proteoglycan retards tumour growth and angiogenesis in preclinical models of GBM and melanoma. PLoS ONE 6 e23062. (doi:10.1371/journal.pone.0023062)

Yoshida S, Higuchi M, Ueharu H, Nishimura N, Tsuda M, Yako H, Chen M, Mitsuishi H, Sano Y, Kato T, et al. 2014 Characterization of murine pituitary-derived cell lines Tpit/F1, Tpit/E and TtT/GF. Journal of Reproduction and Development 60 295-303. (doi:10.1262/jrd.2014-031)

Yoshino A, Katayama Y, Ogino A, Watanabe T, Yachi K, Ohta T, Komine C, Yokoyama T \& Fukushima T 2007 Promoter hypermethylation profile of cell cycle regulator genes in pituitary adenomas. Journals of Neurooncology 83 153-162. (doi:10.1007/ s11060-006-9316-9)

You WK, Yotsumoto F, Sakimura K, Adams RH \& Stallcup WB 2014 NG2 proteoglycan promotes tumor vascularization via integrin-dependent effects on pericyte function. Angiogenesis 17 61-76. (doi:10.1007/ s10456-013-9378-1)

Received in final form 8 March 2016

Accepted 5 April 2016

Accepted Preprint published online 5 April 2016
() 2016 Society for Endocrinology Printed in Great Britain
Published by Bioscientifica Ltd 